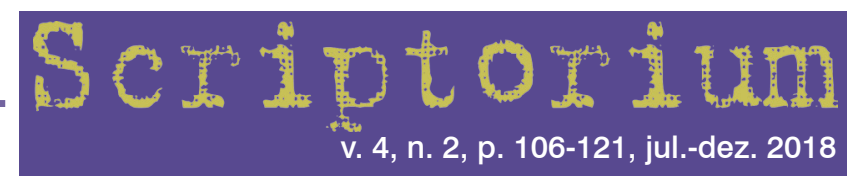

doi)" http://dx.doi.org/10.15448/2526-8848-2018.2.32257

\title{
Literatura In Memoriam: sentidos de legitimação histórica
}

\author{
In memoriam literature: historical legitimation's senses
}

\author{
EDILSON DIAS MOURA \\ Universidade Federal de São Paulo (USP). São Paulo, SP, Brasil
}

\begin{abstract}
Resumo: Este artigo tem como objeto os romances Um homem é muito pouco, de Ronaldo Costa Fernandes, e K., de B. Kucinski; e o poema Estação Paraíso, de Alipio Freire. A partir dessas obras, procura-se estabelecer uma reflexão acerca da literatura contemporânea, nos eixos da temporalidade e da memória, como prática de representação cuja finalidade é caracterizar o estado atual do comportamento social brasileiro em face da sua história política recente.
\end{abstract}

Palavras-chave: romance; contemporâneo; tempo; memória.

\begin{abstract}
This article aims to analyse the novels "Um homem é muito pouco", by Ronaldo Costa Fernandes, "K.", by B. Kucinski; and the poem "Estação Paraíso", by Alipio Freire. Through the reading of these works we try to establish a reflection on contemporary Brazilian Literature in the theoretical perspectives of temporality and memory studies as a representation practice whose purpose is the characterization of the current state of Brazilian social behavior in the face of its recent History.
\end{abstract}

Keywords: Brazilian literature; contemporary novel; time and memory studies.

\section{A contemporaneidade de uma tradição revelada pela metáfora}

[...] estamos sempre no meio de duas lutas ou desesperanças, e a trégua se chama presente. Mal nos recuperamos de uma derrota e há sinais de outra bataIha à frente. A batalha à frente se chama futuro (FERNANDES, 2010, p. 373).

Refletir sobre o significado de contemporâneo literalmente, considerando suas relações históricas e temporais, é um permanente desafio de compreensão. Nele se encontra o presente em oposição ao passado, ou uma história da literatura, cujo pano de fundo depende de reconstituição, métodos de investigação, teorias e atribuições parciais que situam o leitor não contemporâneo a um contexto "depurado" por escolhas: "O leitor não contemporâneo é, por isso, obrigado não só a estabelecer uma relação com o texto, mas ao mesmo tempo a reconstruir os repertórios de que dispunha o receptor da comunicação original. No entanto, esta reconstrução nunca poderá restituir o horizonte original 
da experiência; ela não passa de relativa e particular" (STIERLE, 1979, p.173). Contudo, o diálogo estabelecido entre o leitor contemporâneo à produção, em seu tempo, não deixa de ser marcado pela parcialidade, pelo particular e relativo. Pois, tal leitor, contemporâneo às obras, imerso na própria experiência da origem delas, tende a guiar-se por interpretações que sugerem escolhas pré-definidas. É imperativo pensar um presente dinamizado pelos efeitos de acontecimento que situa o leitor ao "ato" a ele atribuído, isto é, seu papel na decodificação, o que revela sua atuação política ou cultural. Dos efeitos de acontecimento advêm os princípios fáceis de autenticidade (o livro fala do presente, por exemplo) que se incorporam ao conceito de contemporaneidade para dar à obra literária um sentido estético, mas que não preveem a "capacidade do leitor" de ler em " $b$ " um sentido primeiro "a", próprio da metáfora. É o emprego mais literal da palavra, mais realista e naturalista possível da produção para o consumo em massa que determina o papel do leitor contemporâneo. Um presente sem passado e sem sentido para o futuro, ultrapassado em alguns dias, pela substituição sistemática das obras por outras vertiginosamente. Eis um dos sentidos do conceito atual de contemporaneidade. "Para se ter uma ideia da extensão deste conceito no ambiente sociocultural e no espaço midiático, basta observar as duas dimensões que sustentam sua pertinência para a reflexão dos chamados fenômenos massivos: uma dimensão conexa que constitui o 'presente extenso' e uma dimensão emergente que articula o 'presente como novidade'" (SANTANA, 2007, p. 7). A denominação de "contemporâneo" relacionada à literatura, percebe-se de imediato, é mais sincrônica que estética, abrangendo múltiplos níveis de relações sociais do "estar presente" (sobretudo o mercadológico). Dos elementos articulados nessa dinâmica, o ato aquisitivo é o único sentido de atualização (estar em dia com o consumo, descartando sua própria decodificação como "atrasada": leia-se "b", e não "a"): "[...] o constante movimento de atualização dos processos midiáticos se faz importante como ato manifesto que dissolve as práticas de consumo [...] Isso implica modelar as formas de presença como configuradoras dos modos de consumo e, ao mesmo tempo, 'diluir' as representações sociais destas formas como entretenimento" (SANTANA, 2007, p. 9). Independentemente do status (literatura, arte ou entretenimento), esse processo de mercantilização não pode ser esquecido nas análises, ainda que não se deva confundi-lo com valores estéticos ou culturais. Quando se fala de literatura nessas circunstâncias, do presente como novidade, corre-se sempre o risco de que ela possa estar ligada mais a essa dinâmica de mercado do que a algum valor simbólico. E o novo em literatura não se reduz ao processo de aparição no tempo, nem é fruto de um só tempo puramente. É preciso entender as condições materiais, econômica e histórica como campo de múltiplas e possíveis possibilidades de emergência das obras no âmbito das práticas de representação.

Devido a estas condições, as realizações artísticas atuais muitas vezes não nos permitem mais do que meros contrapontos com a história ou as teorias críticas mais consagradas, senão em termos puramente formais. Contudo, essas práticas podem abrir fendas em zonas desconhecidas, nos pondo diante da necessidade de formular um instrumental de ideias capaz 
de abrangê-las; mas podem também resultar em um processo que "transforma o diacrônico do puro acontecido em acontecido-acontecendo" (SANTANA, 2007, p. 7).

Essa dinâmica define práticas literárias distintas e certo desafio ao crítico quanto à tomada de decisão em face de uma realidade marcada pelo efêmero, pela multiplicidade reproduzida e pela tradição na disputa dos espaços de circulação simbólica e circulação capitalista. Estes dois aspectos nos levam a pensar públicos e modos de circulação da literatura em direções opostas. Adiante-se aqui. K., de B. Kucinski, soube com maestria excepcional observar a produção de uma ambivalência, para o leitor, quando abre seu romance com a seguinte aporia: "Quase tudo nesse livro é invenção, mas quase tudo aconteceu". Ela revela um leitor cuja relação com o passado se dá em direções contraditórias, dizendo-o: leia "b" (invenção, metáfora) para entender "a" (história), pois "a" (história) é "b" (invenção), e "b" (inventar) é "a" (história). Logo, não é exatamente do passado que o livro trata, mas sim do passado como metáfora da legitimação histórica do presente, onde a Literatura, como sentido, cumpre um papel específico na decodificação do leitor.

Consideremos o fato literário enquanto acontecimento ampliado de um presente extenso (contínuo), e não o acontecimento em si puramente mercantil, que é o primeiro passo a ser dado na análise do contemporâneo. Embora a produção presente possa ser englobada teoricamente na literatura, há de se distinguir hoje pelo menos duas vias de produção: uma em direção à literatura mercantil de entretenimento (seja fictícia ou não, quase toda, no Brasil, pseudonaturalista-realista); e outra à literatura como prática artística e cultural que transcende o meramente ficcional e diz respeito a questões ligadas à tradição histórica, artística e teórica da literatura (metafórica/alegórica, não meramente imagens do mundo em si). Não à toa a boa literatura só adquire importância quando rompe as barreiras impostas pelo mercado (do aporte financeiro das grandes editoras, que a restringe às vitrines), alcançando os lugares de circulação cultural (museus, bibliotecas, universidades, escolas, fóruns, debates etc.). Wilson Alves-Bezerra bem observa que "Quando, nos anos 2000, [Hilda Hilst e Roberto Piva] entraram no circuito das letras nacionais, via Editora Globo, [...] a obra de ambos já estava concluída" (ALVES-BEZERRA, 2011). Estes autores, como se sabe, antes haviam publicado seus livros em pequenas tiragens por editoras de porte médio ou artesanais. O mesmo ocorre com B. Kucinski, Alipio Freire e Ronaldo Costa Fernandes:

Publicado, em 2005, por uma editora de fora do eixo São Paulo-Rio de Janeiro, é claro que este livro [O viúvo, de Ronaldo Costa Fernandes], uma das poucas obras-primas do romance brasileiro deste início de século XXI, praticamente passou despercebido do leitorconsumidor. Azar dele, pois, se se fiar nas listas dos mais vendidos das revistas semanais que, como se sabe, só reconhecem autores e livros publicados por grandes editoras, vai continuar a ler muito lixo cultural, embora não se negue que são igualmente publicadas muitas obras importantes (GONÇALVES, s. d.).

É possível a uma obra literária circular nos espaços de entretenimento, de circulação mercantil, transformá-la em espetáculo; mas obras de entretenimento dificilmente circulariam no campo das artes, pois que, ao passo que admitissem a interpretação, revelariam seus códigos, exporiam seus 
mecanismos, ofenderiam seu público. O show musical "Us + Them", do cantor inglês Roger Waters, recentemente apresentado no Brasil, revela bem essa característica do "não interpretável" do entretenimento, em que "b" significa " $b$ ", o puramente mercantil, cujo princípio motriz é ocultar os seus códigos, mantê-los em segredo. O fato se deu quando, numa lista de líderes neofascistas notórios apresentados num telão, o nome do candidato à presidência Jair Bolsonaro foi apresentado. O fator metafórico da obra, se contrapondo ao produto do consumo e ao ato da aquisição, produziu no público o terrível mal-estar da interpretação de que " $b$ " significava "a". O que teria sentido de atualização se revelou atraso momentaneamente, o que levou tal público a restabelecer seu vínculo com o presente por meio da vaia, tentativa desesperada de se ver livre da interpretação que o revelara a si mesmo e em contradição com o papel a ele atribuído. A revolta se deu pela perda de tempo, não duas horas ou mais de uma noite esclarecedora, mas de anos ou décadas de uma dedicação esvaziada pela limitação do ato de adquirir como forma de estar presente ou em dia com o mundo, cuja memória "particular" construída da vida como a História "universal" é a-histórica ao menos parcial.

\section{Memória e biografia (metáfora): as formas de mineralização humana (metonímia)}

Tendo-se definido como obra literária aquela cuja capacidade de significação está correlacionada com os papeis de decodificação atribuídos aos seus possíveis leitores, serão analisadas três obras ao longo deste artigo: Um homem é muito pouco (2010), de Ronaldo Costa Fernandes; $K$.
(2011), de B. Kucinski; e Estação Paraíso (2007), de Alipio Freire. Pretende-se, pois, refletir sobre os princípios da apatia filosófica e política atual no âmbito da organização e da divisão do trabalho intelectual e da atividade cultural do país. Não se deseja aqui enfeixá-los nas estreitezas das delimitações acadêmicas; e, menos ainda, nas reduções mercadológicas que dão à arte mero valor de troca, pela presença e consumo. A leitura, ato sempre presente, é o lugar da trégua entre o passado e o futuro, donde se emerge para o campo da atuação política. O tempo do acontecimento em literatura não se reduz ao imediato da aparição. Como já pensava Martí no século XIX: "um grão de poesia basta para perfumar todo um século". Mas é, atualmente, a acepção contrária à permanência, aparentemente ingênua, e do surgimento como novidade que atravessa as mentalidades facilmente, recusando que no tempo que acontece in loco há mais passado do que supomos quando o vemos com a lupa da própria literatura. O presente da enunciação desacelera outro tempo: o da produção regulada pelo relógio e pelo calendário, do imediato ato de consumo como superação dos atrasos no tempo. Com a leitura corrigimos a miopia temporal: o tempo do calendário para, e vemos que os elementos contemporâneos da vida social, da rede de símbolos em circulação, que definem a relevância de sua permanência ou esquecimento, estão mais cheios de passado que as mais remotas ruínas coloniais. $\mathrm{O}$ já literariamente muito velho e continuamente presente, inevitavelmente permanente, alargando a percepção do que seria passado e atualidade - em que o calendário se anula para que se evidenciem, por quaisquer que sejam os vestígios na memória narrativa, os aspectos de ruínas 
desentranhadas nas práticas presentes de escrita - é a vingança de uma antiga reivindicação, tornando a leitura um ato subversivo. Para atualizar-se em literatura, é preciso dar corda ao relógio da memória (recordar) pela leitura, que age como um processo de força oposta ao presente: atua contra o fluxo do imediato em direção ao passado para, ao atingir sua máxima pressão, ganhar o impulso necessário para lançar-se em direção ao futuro. Vejamos isso em Um homem é muito pouco, de Ronaldo Costa Fernandes.

O escritor maranhense constrói sua narrativa combinando elementos inusitados do modelo automatizado do mundo, como alegoria, para desenvolver o modo de funcionamento do raciocínio de suas personagens, suas manias, anseios etc. Mas a reificação clássica, por exemplo, e a consequente degradação da consciência humana, torna-se improdutiva nesse romance como ferramenta analítica, dando lugar ao que podemos chamar de "mineralização dos vivos" ou processo de fossilização social. $O$ autor procura, num processo mais amplo, aprofundar a compreensão de toda sociedade sem recorrer à dissecação tradicional das atitudes mentais de um biografado (não há uma personagem central nesse romance, mas uma multiplicidade de trajetórias formando uma rede de relações, daí as teses de Lukács não funcionarem bem aqui). Assim, embaralhando na trama narrativa funções maquinais e características humanas ${ }^{1}$, procura nos mecanismos contemporâ-

\footnotetext{
Essa característica já se observava em $O$ viúvo, de 2005, mas aqui nos parece que o autor leva a cabo um projeto literário pessoal de efeitos de percepção, não mais em termos de experimentos: "[...] o que se impõe é determinada forma de apreensão da realidade, a particularidade de uma percepção do mundo" (CADEMARTORI, 2005. p.6).
}

neos da vida social o motivo do esgotamento da sensibilidade. $\mathrm{O}$ homem aí, menos que um "mineral" quando destituído de um papel social integrador, humano, imerso nas relações em rede, progride pelo apagamento da memória, da história, fazendo com que as afirmações de presença (icônica) gerem o efeito que em $K$. , de B. Kucinski, se traduz na seguinte percepção:

Alguns anos mais e a vida retomará uma normalidade da qual, para a maioria, nunca se desviou. Velhos morrem, crianças nascem. O pai que procurava a filha desaparecida já nada procura, vencido pela exaustão e pela indiferença. Já não impunha mais o mastro com a fotografia. Deixa de ser um ícone. Já não é mais nada. É o tronco inútil de uma árvore seca (KUCISNKI, 2011, p. 91 - grifos meus).

É com o objetivo de compreender essa "maioria, para qual a normalidade nunca se alterou" que Ronaldo Costa Fernandes abandona a trajetória de um só homem. Um homem é muito pouco, já que nele só se encontram as formas de mineralização da vida humana como efeito semelhante ao que, nesse pequeno parágrafo de $K$., se caracteriza como fossilização em vida: "o tronco inútil de uma árvore seca".

Um homem é muito pouco trata dessa degradação do valor humano, gerada pela insensibilidade, como fenômeno estrutural, em massa, alimentada pela indiferença das múltiplas individualidades ligadas a conexões frágeis de relação. Daí, por exemplo, as categorias lukacsianas "homem problemático/mundo problemático" não poderem auxiliar na tarefa de compreensão do mundo contemporâneo. A ausência da biografia leva à percepção de que é "essência autêntica do eu" se manifestar 
como a própria causa do problema, e não o mundo. A não biografia mostra o "surgimento, desaparição e indiferença" com que tudo acontece: as personagens surgem, cativam, e desaparecem do raio da nossa leitura sem deixar rastros, fazendo com que entremos em contato com outras personagens, que vão emergindo e se apagando ao longo do processo (sem morte, sem corpo), mais pela esperança de sabermos do paradeiro dos outros do que para conhecer as que surgem para substituí-las. O romance produz esse sufocamento da desaparição sem rastros. A única biografia no romance é a do "menino morto", se assim pudesse ser considerada, porque ela é inventada, servindo ao autor para justificar essa ausência do biografado e mostrar alegoricamente a memória degradada pela invenção da biografia (beira-se a pensar nos gêneros biográficos, como Facebook, que substituíram a relação social coletiva-efetiva pela invenção de memórias, nas quais o presente, a história, desaparece).

A alegoria é construída no romance quando se reúne a família de Eurico para comemorar o aniversário da mãe, que perdera um filho. Desde então, ela permanentemente o esperava. Para aliviar a dor dessa ausência, seus familiares inventam uma biografia: "foi ao colégio, fez faculdade, agora o menino morto tinha casado e ainda não tinha filho" (FERNANDES, 2010, p. 258). Eurico, um dos filhos, é relojoeiro, e desde o início desta parte do romance nos habituamos a uma espécie de assimilação da consciência do personagem aos mecanismos das peças do relógio e sua dinâmica de produção temporal. E é nesta reunião de família, em torno da mãe numa cadeira de rodas, que encontramos uma de suas mais belas passagens:
Um pouco da tristeza de Eurico é que não podia fazer a felicidade da mãe. A mãe perdera os rolamentos há muito tempo. Tinha gente na família que dizia que a mãe começou a atrasar as ideias quando morreu o menino morto. E traçavam o percurso de atrasos das ideias da mãe. Lembra a viagem à Bahia? Lembra quando a mãe esqueceu onde morava? Lembra quando a mãe... e davam corda no relógio da memória a lembrar fatos e datas em que a mãe se perdera de si à procura do menino morto (FERNANDES, 2010, p. 259).

A ausência do filho (do corpo) a leva à perda da memória, que produz o "atraso" ou parada num tempo que não existe mais. O humano, não morto, essencial para a lembrança, faz com que, sem ele, os familiares de Eurico busquem em uma ficção biográfica dar corda à memória da anciã para atualizá-la. E como a biografia não tem uma existência autêntica (um menino vivo), é só um eu/ele vazio, leva consequentemente à mãe de Eurico a não viver uma história e que definhe perdida em fatos e datas que não ordenam sua existência numa linha temporal coerente no mundo. A perspectiva é a mesma de $K$. : assim como, pela ausência do filho, resta da mãe de Eurico apenas um busto numa cadeira de rodas, a ausência de Ana, em $K$, faz com que de seu pai reste apenas o tronco morto de uma árvore (viva). $\mathrm{Em} \mathrm{K}$ a ausência do corpo da filha de $K$, prova de sua existência, leva seu pai a solicitar dos rabinos um lugar no cemitério para a colocação da matzeivá (metáfora da biografia como lápide), que é negada pelos sacerdotes; como solução então, em seguida, K tentará fazer um álbum, um livro de memórias de Ana, para preservar sua memória.

O elo das passagens magníficas destes romances virá caracterizada como 
metonímia das pernas, daquela maioria para qual a vida nunca se desviou de seu destino. No início do romance Um homem é muito pouco, conhecemos Clemente, personagem que surge a partir do drama de recuperar um cordão de ouro que Ihe furtaram. Ao encontrá-lo, um dia, no pescoço do ladrão, arranca-o, e suas pernas rejuvenescem trinta anos.

Clemente avançou no pescoço do homem, arrancou o cordão. O cordão na mão the devolveu as forças e suas pernas rejuvenesceram trinta anos. As pernas também pensam. E o que as pernas pensaram naquele momento é que não deveriam ficar ali paradas. As pernas servem para sustentar o sujeito como pilotis, mas também servem para transformar a parte de cima do corpo em um tronco leve. [...] A metade de baixo corresponde às pernas e quando as pernas viram máquina de correr então a parte de cima é apenas um busto que é levado por uma carreta ligeira (FERNANDES, 2010, p. 13).

Clemente, ao longo da narrativa, desaparece sem deixar rastros, e o procuramos pela característica pouco plausível de ter pernas que pensam. Metonímia da memória, quer dizer que cada um pensa por suas próprias pernas, mas não escapam do destino em comum: a mineralização, em que "o tronco leve" se torna apenas uma peça transportada pelas pernas. O número de indivíduos que passam é tão grande que não se pode falar em personagem central. Mesmo o capitão Vaz não é biografado (não tem origem, mas não desaparece). Sua presença sombria leva o leitor a identificá-lo com a figura do autoritarismo como permanência, já que o romance transcorre entre os anos 1950-1970.

Adriano - filho de Eurico e neto da avó perdida em falsas memórias - talvez seja o único a nos dar ideia de uma vida com começo, meio e fim. Apaixonado pela prima, a observa dançando twist, fixando o olhar nas pernas hábeis da moça, comparando a juventude e a velhice da seguinte forma: "As pernas mortas eram o começo de o homem virar mineral. As pernas minerais da avó, por exemplo, já diminuída da cabeça, a transformavam num busto que se recusava a deixar a vida" (FERNANDES, 2010, p. 261). Nessa passagem, encontramos Clemente nas outras pernas. Adriano liga-se a ele quando observa as pernas da prima, compara com as da avó e sintetiza a passagem do tempo da vida pelos seus mecanismos motores. Adriano é talvez o único cujo trânsito de vida no romance tenha algo qualquer de resquício de uma biografia, mas o mecanismo de sua morte não permite a ideia de um fim. O último registro de sua existência na memória da esposa é a decomposição da "carenagem" de uma máquina devolvida à natureza como minério. Adriano morre em um acidente de carro forjado pelo tio, o capitão Vaz, no Aterro do Flamengo. $\mathrm{O}$ acidente segue o mesmo padrão de desaparecimentos produzidos pela Ditadura Civil-Militar, sendo afinal uma vingança do tio, o capitão Vaz, que o culpava da morte do filho, primo de Adriano.

A imagem de Adriano na memória da esposa são os destroços do carro, que, mesmo ela nunca mais tendo passado pelo Aterro, vai sofrendo as ações do tempo físico, enferrujando, sendo invadido pelo mato, restando apenas a ferrugem de sua memória como uma lápide: "A certeza dela é que Adriano vivia outro tempo e outra matéria. O tempo que rói é o tempo que constrói. O tempo que enferruja é o tempo que faz aparecer o ferro em estado 
bruto" (FERNANDES, 2010, p. 274). Aqui vemos com muita clareza o tipo de tempo com que o romance caracteriza a todas as personagens e suas trajetórias: o tempo não histórico, o tempo como ação da natureza, que degrada a matéria humana até seu estado de dissolução total (sem memória), enquanto, no ciclo, a reintroduz à vida como continuidade do processo em outras vidas. Só a permanência do capitão Vaz, que emerge do nada nas histórias das pessoas, difere. Na vida em rede, revelada em ciclo da natureza, ele é o único capaz de numa vigilância extraordinária manter e atar relações contínuas (representa uma memória coletiva). É a partir das relações que fazem de todos indiferentes entre si que sua atividade adquire força política: ele é o permanente, a história.

[...] estamos sempre no meio de duas lutas ou desesperanças, e a trégua se chama presente. Mal nos recuperamos de uma derrota e há sinais de outra batalha à frente. A batalha à frente se chama futuro. Mesmo o passado se pode refazer. Basta que se remonte o passado como álbum de recortes. Basta que se escolha apenas as figuras que queremos e montemos o álbum. $\mathrm{O}$ que não se pode fazer é mentir quando as figuras que queremos desaparecem e as figuras que odiamos insistem em permanecer (FERNANDES, 2010, p. 373-374).

O processo de construção de Um homem é muito pouco tem como objetivo pôr em perspectiva a indiferença entre os entes que leva à construção de uma memória pessoal excessivamente determinada pela exclusão de uma memória coletiva. É sabido que o romance se passa durante a ditadura, mas não há qualquer vestígio de que o sufocamento provocado pela "ausência" pudesse, como aspecto mais comum entre as personagens, uni-los e os retirar do drama particular ou ligá-los por um laço fraternal que "não as pernas". Dessa perspectiva, o romance aponta para a impossibilidade de um só indivíduo (em termos de memória biográfica, particular) ser capaz de conduzir uma transformação ampla da sociedade (que depende de uma memória de todos) como aponta que a indiferença pessoal de cada indivíduo, metonímia do amor às próprias pernas, é o bastante para que toda sociedade vá sendo conduzida uma verdadeira tragédia social: sem funeral, sem lápide, enterrada viva.

\author{
Mas as pernas passam \\ as mulheres passam \\ os amores passam \\ a vida passa. \\ Tudo na vida passa. \\ E envelhece. \\ (ALIPIO FREIRE, Estação Paraíso, p. 119).
}

\section{Sociedade e memória: falsos dilemas}

Desolado pela falta da matzeivá, ocorreu a K. a ideia de compor um pequeno livrinho em memória da filha e do genro. Uma lápide na forma de livro. Um livro in memoriam (KUCINSKI, 2011, p. 79).

Um homem é muito pouco (2010), de Ronaldo Costa Fernandes, abriga certa relação com K. (2011), de B. Kucinski, e Estação Paraíso (2007), de Alipio Freire, que permite leituras num mesmo plano interpretativo. São livros, cada um à sua maneira, cujo enfrentamento político dialoga com o presente, não enquanto universo do imediato, mas como esconderijo do passado. Relembre-se que, há pouco, gabava-se da "jovem democracia brasileira", apegando-se a pequenos supostos avanços da sociedade que a poriam longe, muitos anos-luz, de sua História. Espécie de mal necessário, 
tais avanços serviriam para aprendizagem do futuro. As mazelas antigas da sociedade brasileira não mais ofereceriam qualquer ameaça. Repetiram-se erros fundamentais; sobretudo a incapacidade de enfrentamento das sucessivas tentativas de se apagarem da História os vestígios do autoritarismo tradicional do país, que contraditoriamente se diz democrático e ainda se apresenta assim vergonhosamente, pondo toda sua esperança de que uma eleição venha apaziguá-la.

Segundo pensa o personagem K, e sua ideia cabe exatamente no agora, a corrupção é um problema da democracia, uma fresta ainda de sua existência. A promessa de "desaparecer com ela milagrosamente" não representa novidade política de modo algum: "O Estado não tem rosto nem sentimentos, é opaco e perverso. Sua única fresta é a corrupção. Mas às vezes até esta se fecha por razões superiores. E então o Estado se torna maligno em dobro, pela crueldade e por ser inatingível. Isso ele [K] sabia muito bem" (KUCINSKI, 2011, p. 22).

Com tantos anos procedendo a burguesia brasileira segundo esse padrão de esconderijo ideológico, que fecha o Estado para seu povo, o processo ganhou tom de normalidade. Finge-se convivência. Finge-se tolerância. Finge-se democracia com o desprezo da História, o que exige de B. Kucinski dizer na abertura de sua obra: "Tudo nesse livro é invenção, mas quase tudo aconteceu". O autor para por aí, mas poderia bem levar páginas dirimindo a habilidade de sua possível recepção fingir que está lendo um romance, quando lhe convém o entretenimento; e que leu a história, quando lhe convém se apresentar como consciência histórica. Talvez seja assim que leia nas placas das ruas os nomes de todos estupradores, torturadores e assassinos que elas homenageiam. O autor podia dizer isso. Mas não diz. Sabe o autor com que tipo de dissimulado está lidando. Então passa a dizer que: "Há referências a documentos em apenas duas histórias e somente como recurso narrativo. Cada fragmento ganhou forma independente dos demais, não na ordem cronológica dos fatos e sim na da exumação imprevisível desses despojos de memória, o que de novo obrigou-me a tratar os fatos como literatura, e não como História" (KUCINSKI, 2011, p. 13 - grifos meus).

Esse prólogo ao leitor de Kucinski nos põe diante de dois pontos cruciais para discutir literatura. O que é História aí já está bem resolvido: é a narrativa com base em provas documentais ou materiais, mas que no Brasil tem mais efeito de ficção: a falta de prova é prova do crime de uns, mas não de outros. E essas provas precisam ser reduzidas a pó, sejam materiais (os corpos, os documentos, as biografias) como as imateriais (memorialísticas), mas que não deixam de também ser provas, já que vestígios de uma existência concreta e material. É sabido que nas sociedades ocidentais o que separa a ficção e História corresponde, a partir da Poética de Aristóteles, a aspectos temporais: "o que foi" (passado = História) e o que pode "ser" (presente) e "o que será" (futuro, portanto, ainda "não ser", expectativa) e o que poderia ter sido no âmbito do poético verossímil. O que são documentos, nesse sentido, para o autor de $K_{.}$, e o que é literatura? E por que usou o autor o termo "exumação" para tratar o que ele chama de "despojos da memória"? Por que, embora sendo obrigado a tratá-los como ficção, recorre à metáfora fisiológica de "um corpo", prova da existência? Paul Ricoeur, em suas análises das aporias do tempo, 
abordando o Livro XI das Confissões de Santo Agostinho, considera o "ser do tempo" a própria existência humana compartilhada (não há ser fora do tempo, que é verbo, bem como a presença humana que é ser; segundo Agostinho, só Deus é ser, e não ser, pois fora do tempo: a eternidade é "não tempo"). Ora, trazendo a experiência humana, o ser do tempo, para o campo da narração, que muito nos importa aqui definir, Ricoeur diz: "Narrativa, diremos, implica memória, e previsão implica expectativa. Porém, o que é lembrar-se? É ter uma imagem do passado. Como isso é possível? Porque essa imagem é um vestígio deixado pelos acontecimentos que permanece fixado na mente" (RICOEUR, 2016, p. 22).

A propósito dessa concepção do que se trata "vestígio", Ricoeur nos remete ao texto de Santo Agostinho: "[...] quando se narram coisas verídicas, mas passadas, é da memória que se tiram, não as próprias coisas, que passaram, mas as palavras concebidas a partir das imagens que elas [as coisas, os seres] gravaram no espírito, como vestígios, ao passar pelos sentidos" (AGOSTINHO apud RICOEUR, op. cit.). A pergunta que se faz Ricoeur é "Onde?". Que será toda tese do livro: no tempo, o lugar em que é possível realocar as experiências humanas partilháveis como vestígio deixado pelas coisas, objetos e seres. Assim, a dimensão em que o leitor de literatura vai se encaixar e experimentar os vestígios do passado, "não o corpo, não a causa", mas imagens (efeitos) geradas pela experiência sensorial, é a própria enunciação literária.

Assim, quando Kucinski diz que em $K$. quase tudo é invenção, mas que quase tudo aconteceu, não o faz porque a narrativa seja um híbrido de História e romance, mas sim porque os vestígios na memória não são as coisas em si percebidas ou vistas. Nesse sentido, ainda que "não haja corpo" para exumar, os vestígios da sua existência na memória assumem caráter existencial, não documental material, mas concretizado pela literatura. Portanto, é literatura aquilo que, para seu possível enunciatário, já se estabeleceu como campo de probabilidade mais efetivo do que o documentário histórico. A verdade de que trata a literatura, diferente da História, que é o âmbito do particular, é mais ampla que a mera distinção ficção e verdade, em um país que negou a existência humana por não haver um corpo, uma lápide, um cemitério.

Considerando que a História é o conjunto de bens materiais e seus sentidos de acontecimento documental; e que a ficção seria o conjunto de bens simbólicos, não materiais da existência, cuja circulação se realiza em determinado âmbito da cultura e da sociedade; é da rede de símbolos, da representação nas trocas coletivas, que se tiram as palavras que redescrevem as imagens ocasionadas pela percepção sensorial dos fatos da experiência vivida. Conforme Costa Lima, as representações constituem o "estoque cultural" de uma época: "[...] é este estoque prévio que leva à aceitação da obra" (2003, p. 70); "[...] a inserção em um agrupamento social [...] se realiza, de imediato, pelo acesso a uma rede de símbolos. Esta rede funciona como uma atmosfera. A ela chamamos representação" (idem, p. 87). Portanto, o que define $K$. enquanto literatura é a rede de representações simbólicas compartilhadas com a recepção, e não qualquer critério de sua recepção quanto "verdade" ou "falsidade". E a história de que ele trata é a História do Brasil. A esse critério, portanto, está ligado o valor que a sociedade atribui 
às funções da prática literária, não o que é de fato literatura.

Graciliano Ramos, a propósito, vai se perguntar nas primeiras páginas de Memórias do cárcere se o que escreveu teria sido acontecimento ou só uma impressão sua sobre os fatos, numa direção contrária de Kucinski, mas com a mesma finalidade. Exemplifica com um pormenor interessante, no entanto, que vale aqui mencionar como processo desse tipo de escrita (tanto da narrativa memorialística autobiográfica como da narrativa ficcional biográfica). Graciliano explica-nos que não escreve com base em documentos, mas apenas com os vestígios de fatos fixados na memória. Mas se questiona:

[...] $\mathrm{O}$ ato que nos ocorre, nítido, irrecusável, terá sido realmente praticado? Não será incongruência? Certo a vida é cheia de incongruências, mas estaremos seguros de não havermos nos enganado? Nessas vacilações dolorosas, às vezes necessitamos confirmação, apelamos para reminiscências alheias, convencemo-nos de que a minúcia discrepante não é ilusão. Difícil é sabermos a causa dela, desenterramos pacientemente as condições que a determinaram (RAMOS, 1996, p.37 grifos meus).

O que realmente preocupou o autor foi que o critério de verdade documental dos registros puros pode ser incongruente: "Quase me inclino a supor que foi bom privar-me desse material [provas]" (idem, p. 36). Graciliano tinha alguns registros, mas os atirou ao mar num momento de aperto no traslado para o Pavilhão dos Primários no Rio de Janeiro. E conclui: "Essas coisas verdadeiras podem não ser verossímeis". Ora, verdade e verossimilhança são aspectos bastante diferentes quando se trata de literatura. A escolha pela verossimilhança não significa desapego à verdade; significa que para determinado público, conforme Costa Lima, aceitar uma obra dependerá desse critério: tratar daquele assunto verdadeiro exigia verossimilhança, pois não bastava ser apenas verdade. O problema enfrentado por Graciliano e Kucinski é o mesmo: a negação de prova pela ausência de processo, característico de todo país antidemocrático. Essa questão está tão brilhantemente construída no capítulo "A matzeivá" que precisamos ir a ela mais adiante.

Tanto em K. como em Estação Paraíso, de Alipio Freire, poderíamos dizer que a razão principal dos modos de narrar estão no que aqui vou designar como a matzeivá na primeira, e a poesia in memoriam na segunda, que tentam preservar o mesmo sentido: proteger do esquecimento "Os despojos" da memória, os fragmentos, os fatos, com o mesmo sentido militar de "aquilo que se toma ao inimigo, espólio" (isto é, tudo que a Ditadura não pode tirar), transformando-os em arte poética e prosa ficcional; já que em nível histórico, material do fato, a causa da memória foi negada. É por esse motivo que Kucinski adotou a literatura para tratar dos fatos ocorridos, e não a História ou o jornalismo. O sentido da exumação da memória vai muito além do fato de não se ter reconhecido a materialidade física e existencial da irmã e do cunhado, busca uma compreensão dessa negação que se evidencia na negação da própria literatura como representação ou metáfora. E essa característica do romance (ou novela, como quer o autor) é um diálogo muito profundo com a postura da sociedade brasileira com relação à História, que a marca, que a delimita culturalmente pela "resistência de reconhecer" de todas 
as formas suas crueldades, covardias e mesmo seu caráter antidemocrático, recorrendo aos ardis do esquecimento para se proteger. Explica-se, portanto, o autor dizer que "Tudo nesse livro é invenção, mas quase tudo aconteceu". O capítulo "A matzeivá" é alegórica quanto a essa forma de encarar a verdade e o comportamento comum. O livro está dividido em duas partes: a primeira caracterizada pela negação da História (a Ditadura em si), a segunda pela negação da memória que dela se projeta na literatura como efeito (negação da Democracia, permanência, portanto, de princípios autoritários). A Ditadura negou a "existência humana", a dita "democracia" transformou assassinos e mártires ao não puni-los, e sim perpetuar seus nomes em praças e avenidas como forma de agradecê-los.

\section{Despojos, espólios e hereditariedade}

Tanto Estação Paraíso como K. são, cada um a seu modo, narrativas com o mesmo núcleo temático: desaparecidos políticos cuja existência foi negada em âmbito histórico e documental pelo método de destruição de provas e apagamento de qualquer vestígio dos atos praticados no âmbito do Estado ou da sociedade civil. São, por isso, aqui consideradas obras que adotam como estratégia de resistência a memória elaborada como herança poética e literária ou o que podemos chamar de testamento literário.

\section{1 de março de 1992}

O velho anota

no metrô

seu poema

velho

da vitória

do que houve de mais velho

[...]

Rejuvenescido pela poesia que passa

o velho sorri um sorriso ateu

ciente de que o metrô

não é $\mathrm{O}$ Trem d'A História

e de que deus não existe.

Assim desembarca no Paraíso.

O velho sorri solitário

e despojado de expectativas

[...]

mergulha na chuva fina da noite declina qualquer autoenternecimento ou comiseração pública

faz xixi na árvore da esquina

e prossegue em direção ao vazio

assobiando uma velha melodia

Por que não?

(FREIRE, 2007, p. 119-121 - grifos meus).

Emulando a estrutura de um poema épico, Estação Paraíso, de Alipio Freire, trabalha o canto, a rapsódia, a partir da trajetória de presos políticos encarcerados na ditadura. Em particular, o eu poético projeta pelo verso a passagem, em sua memória, de Aurora: "Aurora / eu te diviso / ainda tímida / inexperiente / das luzes que vais acender / dos bens / que repartirás / com todos os homens" (FREIRE, 2007, p.73). Como Ana Rosa Kucinski Silva, desparecida em 1974, Aurora Maria Nascimento Furtado teve o mesmo destino: presa em 9 de novembro de 1972, faleceria no dia seguinte após 20 horas sob tortura. Os versos citados foram tirados do poema "Prenúncios de Aurora", em que o eu poético, após assistir a "seu coroamento" (remetendo ao episódio camoniano de Inês de Castro, rainha coroada depois de morta), prevê os "bens que repartirás" com todos os homens, a herança de sua ousadia na luta por justiça, direito e por democracia, combatendo um "[...] Estado que não tem rosto nem sentimentos, é 
opaco e perverso" como lembra K. ao se dar conta de que a filha poderia ter sido sequestrada pela polícia política do Estado.

Mas no poema de Alípio, a poesia é sempre, depois de todo labor, insuficiente para dar conta do que é a vida humana. Ainda em "Prenúncios de Aurora", a parte IV é exemplar no que tange ao trabalho poético ser um processo impossível quanto à tentativa de transmitir a vida humana em sua existência concreta, e que só resta o vestígio dela na memória. Daí o resultando de uma busca implacável pelo que, na poesia, poderia aproximar-se de quem foi Aurora.

IV
Garimpo solitário
a cada treva
o universo
e suas leis
os céus
e suas dinâmicas
o ar
e seus fogos
a terra
e suas águas
Depuro
elemento
por elemento

Estou quase cego dessa mineração Mas ainda posso saber Mas ainda posso alcançar [...]

Minha Aurora tem um desenho humano traçado por mestres de obras

[...]

Mas as palavras exatas ainda fogem à minha bateia. (Idem, p. 79).

O que poderia haver de poético na tragédia se traduz em "aurora", uma razão para o futuro: "Havemos de amanhecer / O mundo se tingirá / E o sangue que escorrer será doce / de tão necessário / para colorir tuas pálidas faces / Aurora" (p. 85). E "os bens que repartirás" vêm em forma de composição poética, como "despojo" ao final do canto, quando desembarca na estação do metrô, finalizado o poema: "despojado de expectativas", já que foram entregues "os bens culturais ou poéticos" da memória transformada em literatura aos destinatários do poema, que passam a ser detentores desses bens e, assim, se transfere a "expectativa" do objetivo da luta: o futuro e o que se fará dessa herança. "Assim desembarca no Paraíso. / O velho sorri solitário / e despojado de expectativas / mergulha na chuva fina da noite / declina qualquer autoenternecimento ou comiseração pública". O fim do poema é a aceitação, ao final, de que "Há que / haver sobrado / alguma poesia / Há que / haver / pelo menos / a certeza poética / emblemática / de que / a luta continua / E há que / haver a aceitação / dessa certeza" (p. 77). E a aceita na medida em que a obra se concretiza como fim ou continuidade no campo da literatura in memoriam. E é nessa esteira que $K$. se desenvolve.

Como adiantávamos nesse ensaio, o romance de B. Kucinski se desdobra em duas etapas: a primeira parte do livro nos dá, em perspectiva panorâmica, a busca de K. pelo destino da filha, que como um fio puxado de um tecido desmancha toda trama e revela a ele o modus operandi da repressão política. Tais atividades são deduzidas por K., mas sabemos tudo de antemão em função da estratégia narrativa de adotar um narrador onisciente, conduzindo o leitor nos diversos ambientes em que se desenrola a tragédia. O capítulo "A abertura" esclarece toda a rede de atividades do Estado e da sociedade civil: 
"Mais dia menos dia esses documentos vão para a imprensa e nos fodemos. O Robert diz que agora é a hora de limpar os arquivos, não deixar prova" (KUCINSKI, 2011, p.77). Eis o motivo de no Brasil a história documental esteja morta já nos arquivos e como a função memorialística literária a ressuscita.

É evidente a caracterização desse capítulo pelos sentidos de "abertura política" proposta pelo governo civilmilitar: tanto no que tange à anistia como o processo histórico de apagamento de todas as provas das violações dos direitos humanos produzidas no período, dificultando qualquer investigação. Assim, o capítulo "A matzeivá", estrutura-se no romance como um divisor e a síntese da representação de dois momentos da vida política brasileira, caracterizando o comportamento da sociedade em face desses dois períodos, o anterior à abertura e o posterior: a matzeivá, a literatura in memoriam.

O momento em que K. decide interpretando as táticas empregadas pelos repressores como evidência da morte da filha - procurar um rabino para que o autorize pôr no cemitério israelita do Butantã a lápide da filha tem notório sentido alegórico da caracterização a que chamamos atenção. O personagem ouvirá de imediato: "O que você está pedindo é um absurdo, colocar uma lápide sem que haja corpo..." (p. 79). A tática de negação da História é o mesmo na Universidade de São Paulo: lá o processo vai ser "demissão por justa causa, abandono de posto de serviço" em vez de "sequestro". Desenrolase nesse processo algo extraordinário: "K. sente com intensidade insólita a justeza desse preceito, a urgência em erguer para a filha uma lápide, ao se completar um ano da sua perda. A falta da lápide equivale dizer que ela não existiu e isso não é verdade" (p. 80). Aqui se dá a superposição dos níveis discursivos do romance: a falta da literatura equivaleria a "não existência da História", do mesmo modo que a não colocação da lápide significa que a filha não existiu.

A discussão dos rabinos é extraordinária. Remete ao processo do livro como método de reconhecimento dos discursos sociais. Com o fim do capítulo "A abertura", fecha-se a etapa do apagamento da existência humana e dos crimes contra ela cometidos. E no capítulo seguinte, nega-se sistematicamente a existência da memória que o pai tem da filha, que é causa da narrativa, levando-o à construção de uma biografia para efetivar o reconhecimento da existência. A lápide, a matzeivá, é crucial como metáfora da literatura. Daí por diante os diálogos lembram o debate jurídico, cujo apego fingido a filigranas da lei, a ninharias, vai sendo usado para se desvencilhar do reconhecimento de culpa: "A colocação da matzeivá é apenas a etapa final do sepultamento [...] Era colocada para os túmulos não serem profanados; os corpos não serem violados; [...] se não há corpo, não há o que profanar" (p.81). Eis as táticas dos rabinos para, protegendo a ausência de prova, profanar a História e eximirem-se da participação do processo de "queima de arquivo". Aceitar a matzeivá seria aceitar que o crime foi cometido.

O jogo aí é explícita caracterização da postura da sociedade brasileira: para que não seja responsabilizada pela História, nega sua existência pela ausência de prova material que ela mesma destruiu. Desmascara-se, portanto, a mesma estratégia enunciada no fim do capítulo "A abertura": no Brasil chamou-se redemocratização o processo de apaga- 
mento da História e de sua memória. Pois, se a matzeivá fosse aceita, reconhecida seria a existência dos desaparecidos e, consequentemente, o crime praticado não permitiria a anistia. A matzeivá é alegoria da democracia desejada; a "A abertura", alegoria da democracia permitida. Leia-se por matzeivá "democracia": "Desolado pela falta da matzeivá, ocorreu então a K. a ideia de compor um pequeno livro em memória da filha e do genro. Uma lápide em forma de livro. Um livro in memoriam. [...] De posse do material, K. procurou a pequena gráfica do bairro que havia sido de um anarquista italiano" (p. 83). Aí temos a passagem da luta pela democracia para a luta pela literatura como forma de testamento e prova da existência. Negar a literatura, é negar tudo. Traçado o plano, reunidas as lembranças da filha, fotos dela e das amigas, pertences etc., pede orçamento do livrinho para distribuir entre os conhecidos. Volta no dia seguinte à gráfica e ouve do dono o seguinte: "Como o senhor teve o atrevimento de trazer material subversivo para a minha gráfica? Pegue isso e dê o fora, nunca mais apareça com esse tipo de coisa. Onde já se viu, material subversivo, uma desaparecida política, uma comunista. Ela não era comunista?'" (p. 84). ${ }^{2}$ Eis o sentido da literatura in memoriam contemporaneamente.

Síntese de toda trama do romance, o capítulo é metaliterário. Ele orienta, pela sua própria estrutura discursiva, o motivo

\footnotetext{
2 A aspa simples indica "as aspas usadas" no trecho original do livro. Em evento realizado dia 15 de julho de 2017, na Unibes Cultural, e promovido pela Escola Fórum das Artes, após uma pequena exposição sobre esse trecho, o autor tomou a palavra e disse que ele, no livro, foi a única parte não inventada: as palavras usadas ali foram tiradas da recusa de uma editora na avaliação do original para uma possível publicação, antes de ele ser lançado pela Editora Expressão Popular.
}

de que um livro possa ser escrito, pelo menos no Brasil, com a ambivalência de que tudo é inventado e, ao mesmo tempo, acontecimentos verídicos. Projetando a capacidade de a obra literária testemunhar mais do que a História, supõe dizer, isto é, apontar-nos, pelo reconhecimento de sua estrutura, características do mundo que regem as ações e comportamentos como algo antigo, permanente e atualizado.

Assim, não é a propriedade de dizer novidades que caracteriza a literatura, mas sim de desvendar o que "não é" novo, contradição que sobrevive pela mera obviedade. Vivemos num país em que as palavras racistas têm sido sistematicamente perseguidas e condenadas pelos seus usuários. Mas o que ocasiona a palavra segue intacto. As palavras existem para designar coisas, fatos, objetos, relações que existem à mercê delas mesmas. O racismo, a indiferença, a negação da democracia, vão sobreviver, por mais que as palavras sejam apagadas, se a sua causa ainda existir: as estruturas que impedem compartilhar oportunidades têm nomes descentes e não agridem ninguém, dão brilho a seus idealizadores. Essas estruturas são racistas, antidemocráticas, "fingidas" como os rabinos de $K$. A justiça, toda reivindicação dela, é um direito, cuja negação se dá pela invenção de nomes. Lembra o ensaio de Alberto Manguel, "Um leitor no Bosque do Espelho", em que diz o autor argentino: "acostumada a pôr sua experiência da realidade em palavras, Alice descobre de repente que nada tem de fato um nome" (MANGUEL, 2000, p.22). E continua:

Todas as verdadeiras leituras são subversivas, a contrapelo, como Alice, uma leitora sã de espírito, descobriu 
no mundo do espelho batizantes malucos. Um primeiro-ministro canadense arranca uma ferrovia e chama o ato de "progresso"; um empresário suíço trafica produtos de pilhagem e chama isso de "comércio"; um presidente argentino protege assassinos e chama isso de "anistia". Contra esses enganadores, o leitor pode abrir as páginas de seus livros. Nesses casos, ler nos ajuda a manter a coerência no caos, não a eliminá-lo; não a enfeixar a experiência humana em estruturas verbais, mas a permitir que ela progrida em sua própria maneira vertiginosa; não a confiar na superfície brilhante das palavras, mas a investigar a escuridão (Idem, p. 27).

As obras de Alipio Freire, Ronaldo Costa Fernandes e B. Kucinski são esse convite ao leitor a abrir as páginas de seus livros e descobrir o que esconde a "superfície brilhante das palavras", a escuridão por trás do efeito estético, e nos fazer refletir, por exemplo, por que "A abertura" em 1985 não foi democrática, e sim desdobramento de outra etapa da repressão que redundou, na atualidade, com a volta do fascismo no Brasil. O neofascismo hoje, como nos anos 1930, tem prometido como solução eliminar o comunismo do território. Mas o que se tem chamado comunismo? Os direitos humanos? Os direitos humanos são uma reivindicação democrática feita por democratas e assinada por países democráticos. De onde vem então essa ideia senão de uma memória que a História do Brasil fingindo combater preservou. Não se pode dizer que somos um país ou um povo sem memória. Não podemos, conforme Costa Fernandes, mentir quando as figuras que queremos desaparecem e as figuras que odiamos insistem em permanecer.

\section{Referências}

ALVES-BEZERRA, Wilson. Ainda sobre a Literatura Brasileira contemporânea. Disponível em: <http:// blogs.oglobo.globo.com/prosa/post/ainda-sobreliteratura-brasileira-contemporanea-384812. html>. Acesso em: 5 ago. 2017.

CADEMARTORI, Ligia. No espaço da linguagem. In: FERNANDES, Ronaldo Costa. O viúvo. Brasília: LGE Editora, 2005.

FERNANDES, Ronaldo Costa. Um homem é muito pouco. São Paulo: Nanquim, 2010.

FREIRE, Alipio. Estação Paraíso. São Paulo: Expressão Popular, 2007.

GONÇALVES, Adelto. O viúvo, um acontecimento literário. Jornal de Poesia. Disponível em: <www. jornaldepoesia.jor.br/rcfernandes.html\#adelto $>$. Acesso em: 5 ago. 2017.

LIMA, Luiz Costa. Mímesis e modernidade: formas das sombras. Rio de Janeiro: Paz \& Terra, 2003.

KUCINSKI, B. K. São Paulo: Expressão Popular, 2011.

MANGUEL, Alberto. No bosque do espelho: ensaios sobre as palavras e o mundo. São Paulo: Companhia das Letras, 2000.

MOURA, Edilson Dias; TOMMASO, Mario. Reflexões acerca da escrita na atualidade. Opiniães - Revista dos Alunos de Literatura Brasileira, São Paulo, v. 1, n. 2, 2011, p. 122-128.

RAMOS, Graciliano. Memórias do cárcere. Rio de Janeiro/São Paulo: Record, 1996. v. 1.

RICOEUR, Paul. Tempo e narrativa. A intriga e a narrativa histórica. vol. 1. São Paulo: WMF Martins Fontes, 2016.

SANTANA, Gelson. Nota introdutória ao conceito de contemporâneo. In: Cinema, comunicação e audiovisual. SANTANA, Gelson (Org.). São Paulo: Alameda Casa Editorial, 2007.

STIERLE, Karlheinz. Que significa a recepção dos textos ficcionais? In: JAUSS, H. R. et al. (coordenação e tradução de Luiz Costa Lima). A literatura e o leitor. Rio de Janeiro: Paz \& Terra, 1979.

Recebido em: 10/10/2018

Aceito em: 18/12/2018

EDILSON DIAS MOURA

Doutorando no Programa de Pós-Graduação em Literatura Brasileira na USP (DLCV-FFLCH-Letras)

(D) https://orcid.org/0000-0002-6784-5150

<edilson.moura@usp.br> 